Canadian Journal of Bioethics

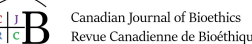

Revue canadienne de bioéthique

\title{
Review of: Greenberg R.A., Goldberg A.M., Rodriguez-Arias D. (eds.) (2016) Ethical Issues in Pediatric Organ Transplantation
}

\section{Josée Bonneau}

Volume 1, Number 2, 2018

URI: https://id.erudit.org/iderudit/1058286ar

DOI: https://doi.org/10.7202/1058286ar

See table of contents

Publisher(s)

Programmes de bioéthique, École de santé publique de l'Université de Montréal

ISSN

2561-4665 (digital)

Explore this journal

Cite this review

Bonneau, J. (2018). Review of [Review of: Greenberg R.A., Goldberg A.M., Rodriguez-Arias D. (eds.) (2016) Ethical Issues in Pediatric Organ

Transplantation]. Canadian Journal of Bioethics / Revue canadienne de

bioéthique, 1(2), 81-81. https://doi.org/10.7202/1058286ar

This document is protected by copyright law. Use of the services of Erudit (including reproduction) is subject to its terms and conditions, which can be viewed online.

https://apropos.erudit.org/en/users/policy-on-use/ 


\title{
Review of: Greenberg R.A., Goldberg A.M., Rodríguez-Arias D. (eds.) (2016) Ethical Issues in Pediatric Organ Transplantation
}

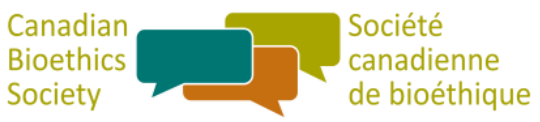

En collaboration avec / In collaboration with

Josée Bonneau ${ }^{1}$

Mots clés

pédiatrie, transplantation d'organes, éthique, droit

\author{
Keywords \\ pediatric, organ transplantation, ethics, law
}

In their work, Greenberg, Goldberg and Rodriguez-Arias [1] explore the many complex ethical issues related to pediatric organ transplantation. Topics such as: children as living donors, deceased donation, newborn as potential donors, emerging challenges related to organ donation and organ allocation are some of the delicate themes that are thoroughly discussed. The authors shed light on many of the ethical dilemmas related to pediatric organ transplantation and provide readers the opportunity to deepen their knowledge and engage in reflection.

This book brings together a multitude of ethical issues related to pediatric organ transplantation. The authors have brought together the work of national and international experts to provide readers with a global and thorough body of knowledge regarding pediatric organ transplantation. This book is an excellent cross-section of the varied legal and ethical issues that arise in the context of caring for children in need of an organ transplantation.

Each chapter of the book offers an in-depth analysis of a precise ethical issue that occurs in pediatric organ transplantation. Explicit examples allow the reader the opportunity to deepen their knowledge and reflect critically. A deeper understanding the uniqueness of these issues is extremely important thus making this book an excellent resource for all practitioners. Many perspectives are offered by experts in the field for each of the topics presented. This allows readers the possibility to explore situations from different aspects. The clinical nature of the issues presented as well as the health provider, child and family perspectives also allow for application to practice.

Greenberg, Goldberg and Rodriguez-Arias have successfully provided readers with the opportunity to gain knowledge and insight into the many ethical issues surrounding pediatric organ transplantation. They have brought together experts from across Canada as well as international practitioners and scholars who together provide the foundation for this unique body of knowledge. This book is a valuable resource and has truly allowed me to explore the many different ethical issues related to pediatric organ transplantation.

As we know, pediatric and adult issues are very different. Legal and ethical perspectives vary when we are caring for a pediatric population. Issues of vulnerability, of best interest and of consent can be further complicated. This book allows for a better understanding of these complex issues by exploring organ transplantation from a pediatric perspective. This is truly a unique and inspiring book that has empowered me to have the knowledge and language to address ethical issues in pediatric organ transplantation.

Many thanks to the authors for their unique contribution to pediatric ethics.

Conflit d'intérêts

Aucun déclaré

Édition/Editors: Evelyne Durocher \& Patrick Gogognon

\section{Affiliations}

${ }^{1}$ Ingram School of Nursing, McGill University, Montréal, Canada

Correspondance / Correspondence: Josée Bonneau, josee.bonneau@mcgill.ca

Reçu/Received: 9 Oct 2018

Publié/Published: 25 Oct 2018 (CBS/SCB: Sept 2017)
Conflicts of Interest None to declare
Les éditeurs suivront les recommandations et les procédures décrites dans le $\underline{\text { Code of Conduct and Best Practice Guidelines for Journal }}$ Editors de COPE. Plus précisément, ils travaillent pour s'assurer des plus hautes normes éthiques de la publication, y compris l'identification et la gestion des conflits d'intérêts (pour les éditeurs et pour les auteurs), la juste évaluation des manuscrits et la publication de manuscrits qui répondent aux normes d'excellence de la revue.

\section{References}

1. Greenberg RA, Goldberg AM, Rodríguez-Arias D. (eds.) Ethical Issues in Pediatric Organ Transplantation. Switzerland: Springer International Publishing, 2016. 